\title{
Medicinal bioactivites and allergenic properties of pumpkin seeds: review upon a pediatric food anaphylaxis case report
}

\author{
${ }^{1}$ Department of Dermatology, Allergology and Photobiology, Centre Hospitalier Universitaire de Grenoble, Grenoble, France
} ${ }^{2}$ Department of Pediatrics, Hôpital Couple Enfant, Centre Hospitalier Universitaire de Grenoble, Grenoble, France

\section{KEY WORDS}

allergens; child; food allergy;

medicinal activity; pumpkin seed

\section{Corresponding author}

Catharina Chatain

Centre Hospitalier Universitaire de Grenoble

BP 217, 38043 Grenoble Cedex 09, France

Phone: +33667078725

Fax: +33476765558

E-mail: cchatain@chu-grenoble.fr

\section{Doi}

10.23822/EurAnnACI.1764-1489.19

\begin{abstract}
Summary
Food allergy to pumpkin seed is considered very rare, and only some isolated case reports have so far been published. We report here a case of food anaphylaxis to pumpkin seed in an eightyear-old boy, who tolerated all other edible seeds, peanut and tree nuts, as well as pulp of different kinds of pumpkins and other fruits of the Cucurbitaceae family. From this observation, a review of the botanical, historical, medicinal and allergenic aspects of pumpkin and its seeds is proposed. With the advent of diets rich in omega-3 and omega-6 polyunsaturated fatty acids, edible seeds like pumpkin seed have been incorporated in the modern diet. Their incremental use in the food-processing industry might contribute to an increase in food allergy to pumpkin seed in the future.
\end{abstract}

\section{Introduction}

Comestible seeds like sesame, sunflower, flax, pumpkin and poppy seeds are increasingly incorporated in the modern diet because of their potential health benefits, associated with their high concentration in omega- 3 and omega- 6 polyunsaturated fatty acids, and with some of their biologically active components. Along with changing diet habits, hypersensitivity reactions to seeds are augmenting, but still are rarely suspected.

Pumpkin belongs to the Cucurbitaceae family. Its seeds have been used as traditional medicine in South Asia and both Americas. Since a few decades, as alternative medicine and healthy nutrition become increasingly popular, pumpkin seed has gained interest in the field of diet and disease research. Its various medicinal bioactivities, reviewed in this report, have contributed to qualify pumpkin seeds as an attractive nutriment, but hence also as a potential emerging allergen food source.
Food allergy to pumpkin seed is considered an extremely rare allergy. Only one case of severe allergy in a child after ingestion of pumpkin seeds has previously been reported in the literature (1). We describe another pediatric case of food anaphylaxis to pumpkin seed.

\section{Materials and methods (case report)}

An eight-year-old boy, with a history of allergic asthma to house dust mites, outgrown IgE-mediated food allergies to cow milk and cashew nut and persistent goat and sheep milk allergy, declared a grade 3 anaphylaxis with deep faintness, vomiting, facial and pharyngeal edema almost immediately after eating a German multigrain bread bun containing sunflower and pumpkin seeds. The parents treated the reaction with oral antihistamines and corticoids, but on worsening of symptoms during the following ten minutes did not hesitate to use the child's epineph- 
rine auto-injector $\left(\right.$ Epipen $\left.^{\circledR}\right)$ with immediate efficacy. The boy was hospitalized for 24 hours in the nearby hospital.

At about 5 years of age, the child had already experienced an episode of faintness with nausea and oropharyngeal pruritus after ingestion of a bite of bread containing seeds, resolved rapidly after oral intake of antihistamines. This incident had therefore not been reported to the allergist before.

The child consumed without any problems the different cucurbits (different pumpkin and squash varieties, zucchini, cucumber and melon varieties including cantaloupe, canary melon and watermelon), peanuts and all kinds of nuts (almond, hazelnut, walnut, pecan nut, pistachio, cashew nut, Brazil nut, macadamia nut, coconut, pine kernel).

\section{Results}

We tested the pulp and the seeds of cultivars of the three Cucurbita species commonly found in Europe: Cucurbita pepo, Cucurbita maxima, Cucurbita moschata. In search of cross reactions, we tested also the pulp and the seeds of some cultivars of the two cu-

Figure 1 - Prick to prick test to pumpkin seed (C. pepo).

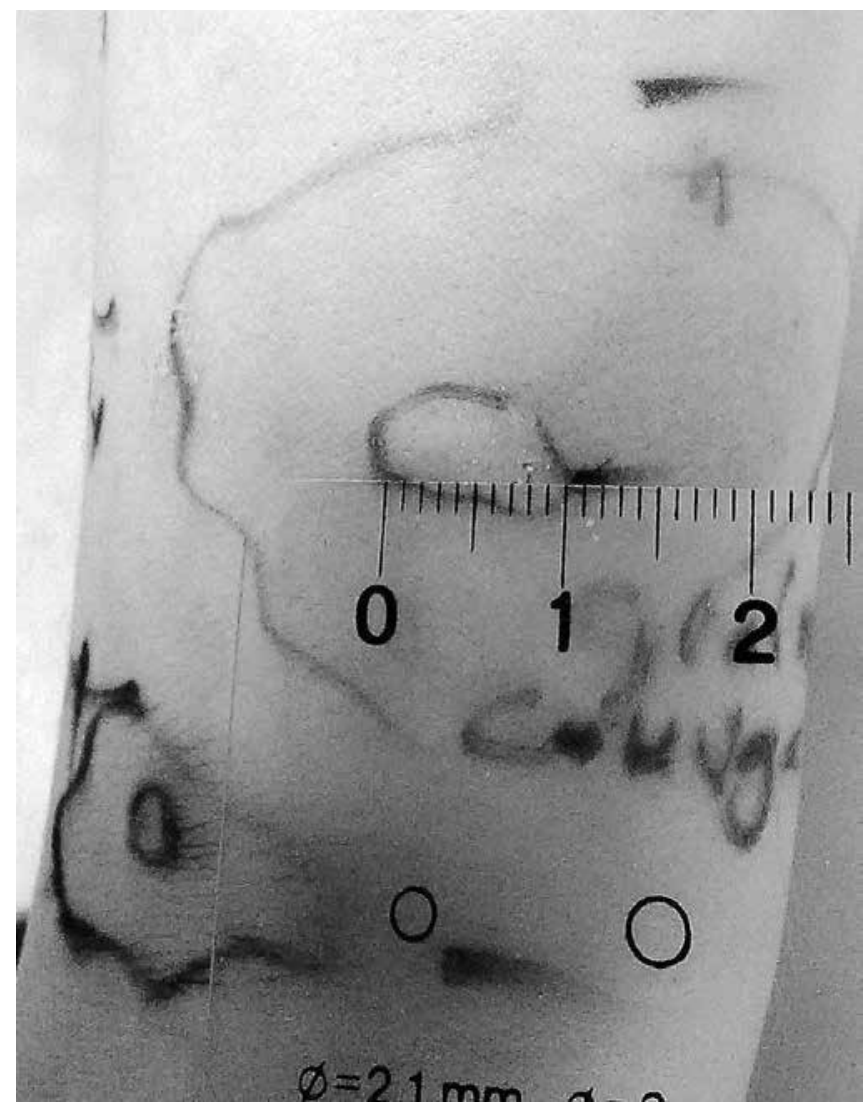

curbit genera Cucumis and Citrullus: three Cucumis melo or muskmelon varieties (cantaloupe, canary melon, honeydew), Cucumis sativa or cucumber, as well as Citrullus lanatus or watermelon. All kinds of other edible seeds and their oils (sesame, sunflower, flax, poppy), nuts, and flour types were tested for the same reason.

Skin prick-to-prick testing demonstrated a large positive $10 \mathrm{~mm}$ wheal and flare responses to different kinds of pumpkin seeds (Figure 1 and 2), Cucurbita pepo Lady Godiva, French Cucurbita maxima Rouge vif d'Estampes, French Cucurbita moschata Musquée de Provence, and a $5 \mathrm{~mm}$ wheal and flare response to Cucurbita moschata butternut squash seed, while the histamine control was $4 \mathrm{~mm}$. Prick-to-prick skin tests with raw and cooked pulp of these pumpkin varieties were negative, as well as with immature zucchini (Cucurbita pepo) seeds, raw and cooked zucchini pulp and pumpkin seed oil.

Prick-to-prick tests were slightly positive with sunflower, flax and sesame seed, creating a $3.5 \mathrm{~mm}$ wheal. Poppy seed prick-toprick tests were negative as well as prick-to-prick tests with linseed oil, sesame oil, rape seed oil (colza oil), cucumber, seeds and pulp of cantaloupe, honeydew, canary melon and watermelon.

Figure 2 - Prick to prick test to different pumpkin seeds.

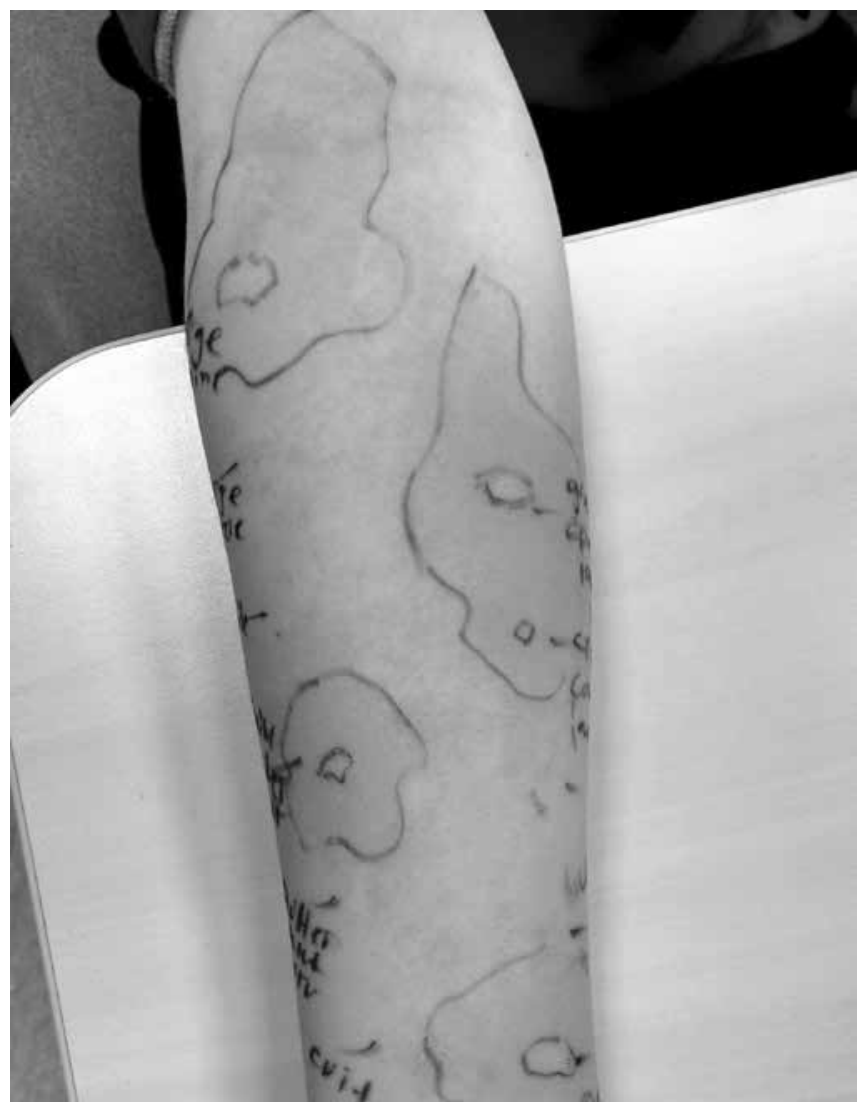


Prick-to-prick skin tests remained also negative to peanut, all kinds of nuts (almond, hazelnut, walnut, pecan nut, pistachio, cashew nut, Brazil nut, macadamia nut, coconut, pine kernel) and flours (wheat, rye, oat, soy, lupine, buckwheat, chestnut). Specific IgE to pumpkin seed (C. pepo) were positive at 3.75 $\mathrm{KU} / \mathrm{L}$, while they remained negative to pumpkin pulp, as well as to sunflower seed, flaxseed, sesame seed and poppy seed. Furthermore, negative results were found for specific $\operatorname{IgE}$ to recombinant peach proteins pru p 1 (PR 10), pru p 3 (LTP), pru p 4 (profilin), peanut and hazelnut PR 10 (ara h 8 and cor a 1, respectively), peanut, hazelnut and walnut LTP (ara h 9, cor a 8 and jug $\mathrm{r} 3$, respectively), peanut storage proteins ara h 1 ( $7 \mathrm{~S}$ globulin or vicillin), ara h 2 ( $2 \mathrm{~S}$ albumin) and ara h 3 (11S globulin or legumin), cashew nut storage protein ana o 3 (2S albumin), walnut storage protein jug $\mathrm{r} 1$ (2S albumin), and hazelnut storage protein cor a 14 (2S albumin), whereas specific $\mathrm{IgE}$ to hazelnut storage protein cor a 9 (11S globulin) were slightly positive at $0.13 \mathrm{KU} / \mathrm{L}$ (by ImmunoCAP ${ }^{\circledR}$ Thermo Fisher Scientific, Phadia AB Uppsala Sweden). Total serum IgE measured $212 \mathrm{KUI} / \mathrm{L}$, and serum baseline tryptase $8.06 \mu \mathrm{g} / \mathrm{L}$. An oral challenge test with a seed mix (sunflower, flax, sesame and poppy seed) was proposed on account of the cutaneous sensitization to these seeds, and remained negative at significant doses (cumulative dose of $20 \mathrm{~g}$ ).

\section{Discussion}

\section{Botanical aspects}

Cucurbitaceae, also called cucurbits, are herbaceous climbers or woody lianas grouped together in a plant family consisting of about 95 genera and 950-80 species (2). The Cucurbitaceae family ranks among the highest of plant families for number and percentage of species used as human food. Edible genera include:

- Cucurbita, squash, pumpkin, zucchini, some gourds

- Citrullus, watermelon (C. lanatus), C. colocynthis

- Cucumis, cucumber (C. sativus), various melons (C. melo).

- Five cucurbita species have been domesticated:

- Cucurbita argyrosperma Huber, e.g. Mexican cushaw pumpkin

- C. ficifolia Bouché, e.g. South American black seed gourd, known also as fig leaf squash or Malabar gourd

- C. maxima Duchesne ex Poiret, some cultivars: all giant pumpkins, Rouge Vif d'Estampes, Red kuri squash also known as Hokkaido squash, French turban squash, Buttercup squash, Hubbard squash

- C. moschata (Duchesne ex Lam.) Duchesne ex Poiret, some cultivars: Musquée de Provence, Butternut squash, Crookneck type squash, Banana Squash

- C. pepo L., some cultivars: pumpkin, Acorn squash also known as Des Moines Squash or Pepper Squash, Spaghetti squash, Straightneck squash, zucchini $(3,4)$.
Species of cucurbits are cultivated in most countries of the world, where crop plants can be grown in the summer at warm temperatures. All species are sensitive to frost. Most of the plants in this family are annual creeping or climbing plants (vines), with five vigorous stems and five-lobed or palmately divided leaves with long petioles. The leaves are alternately arranged on the stem. The stems are hairy and pentangular, and have springlike tendrils. Many species have large, yellow or white flowers with five fused petals. The flowers are unisexual, with male and female flowers on different plants (dioecious) or on the same plant (monoecious). The large and fleshy fruit, usually with a hard outer covering, is often a kind of modified berry called a pepo. The seeds are ovate-elliptical, flattened, $15-25 \times 7-12$ $\mathrm{mm}$, of dark brown to black or creamy white color (2-6).

\section{Historical aspects}

Cucurbitaceae probably evolved in the Late Cretaceous, some 60 million years ago (2). The varieties of pumpkin and squash originated in various places throughout the Americas, specifically central Mexico, Peru and the Eastern side of the United States. Archaeological records suggest that Cucurbita species were one of the first plants to be domesticated $(3,5,7)$. Cultivation by the inhabitants of Guila Naquitz cave date between 10,000 and 8,000 $\mathrm{BC}$, predating corn and beans by more than 4,000 years (8). Cucurbita species were brought to Europe after Columbus' exploration after 1492 (5). Cucumis and Citrullus species originated in Africa and Western Asia (India). Finds in Egyptian tombs dating from the 16th to the 12th century BC have revealed that sweet cucurbits were being eaten by pharaohs, as well as later on by Roman and Byzantine empires from the 2nd to the 6th centuries $(3,5,9)$.

In Austria and adjacent countries, pumpkins have been grown for production of oil for about three centuries. Because the seed coat comprises about $20 \%$ or more of the seed weight, new technologies were sought to utilize in oil seed pumpkins. At about the turn of the 20th century, a shell-less seed variant was discovered and subsequently bred because of the greater efficiency in oil recovery, since the seeds did not have to be laboriously hand shelled (10). In the last two decades, pumpkin seed has been the focus of increased interest in the field of diet and disease research due to the potential health benefits associated with some of its biologically active components. With the advent of diets rich in omega-3 and omega- 6 polyunsaturated fatty acids, pumpkin seeds and other seeds have been incorporated in the modern diet. Pumpkin seeds are used as additives to confectionery and bakery products or eaten as snacks after being salted and roasted. Pumpkin seed oil (especially that obtained from hull-less seeds) is utilized by both pharmaceutical and food industries (in the latter generally as salad oil) (11). Besides its use as food, pumpkinseed flour is used by fishermen for baits to lure fish (12). 


\section{Phytochemistry of pumpkin seeds}

Pumpkin (Cucurbita sp.) seeds are a good source of essential micro-elements such as $\mathrm{K}, \mathrm{Na}, \mathrm{Cr}, \mathrm{Mg}, \mathrm{Zn}, \mathrm{Cu}, \mathrm{Mo}$ and $\mathrm{Se}$. Seeds are valued for their high protein amount $(30-37 \%)$ with presence of all 9 essential amino acids, as well as for their high quantity of lipids (40 - 50\%) containing essential fatty acids, especially alpha linoleic acid (omega-6). The lipid fraction of pumpkin seeds encloses also high concentrations of bioactive components: phytosterols, carotenoids, tocopherols and phenolic compounds $(6,10,11,13,14)$. Fat-soluble tocopherols and carotenoids, as well as phytosterols and polyphenols, have antioxidant activity and play an important role in decreasing DNA damage, diminishing lipid peroxidation, maintaining immune function, and inhibiting malignant transformation or proliferation $(11,13-15)$.

\section{Medicinal bioactivities of pumpkin seeds}

The seeds of Cucurbita sp. have been traditionally used as medicine in China, India, Korea, Yugoslavia, Argentina, Brazil, Mexico and America, to treat intestinal parasites, urinary infections, bladder and kidney stones, biliary vesicle and prostate problems. Due to their anti-inflammatory and anti-oxidative properties, pumpkin seeds are thought to slow the aging process, reduce the risk of cataract development, promote wound healing and reduce symptoms of inflammatory diseases such as arthritis $(6,10,14-16)$. Broadspectrum antibacterial and antifungal activity has been reported for different peptides found in pumpkin seed oil, such as $\alpha$ - and $\beta$-moschins (MW: $12 \mathrm{kDa}$ ), MAP28 (MW: $28 \mathrm{kDa}$ ), MAP2 (MW: 2249D), MAP4 (MW: 4650D), MAP11 (MW: $11696 \mathrm{D}$ ), peptide (MW: $8 \mathrm{kDa}$ ), and pumpkin albumin $2 \mathrm{~S}$ $(6,10,17)$. Curcubitin and the protoberberine alkaloids berberine and palmatine have shown anthelminthic activity (18), which was reported at the minimum inhibitory concentration of $23 \mathrm{~g}$ of pumpkin seed in $100 \mathrm{ml}$ of distilled water in preclinical studies (10).

Because of their antimutagenic and immunomodulatory activity, pumpkin seeds have also been associated with lower risk of gastric, breast, lung, prostate and colorectal cancers $(6,17,19,20)$. The ribosome-inactivating proteins Moschatin and Cucurmosin from the mature seeds of pumpkin (C. moscha$t a)$ were reported to inhibit melanoma cell proliferation as well as leukemia, lung adenocarcinoma and pancreas cancer cell proliferation for the latter (21-23). Pumpkin albumin $2 S$ was shown to exhibit a strong anticancer activity toward breast adenocarcinoma (MCF-7), ovarian teratocarcinoma (PA-1), prostate cancer (PC-3 and DU-145) and hepatocellular carcinoma (HepG2) cell lines (17).

Rich in omega-3 and omega- 6 fatty acids, phytosterols and secoisolariciresinol, a lignan acting as phytoestrogen and anti-ox- idant, pumpkin seeds were shown to have protective activity against cardiovascular diseases and non-alcoholic fatty liver disease, by improving plasma lipid profile, lowering blood pressure and attenuating arthrosclerosis development (24-26). Bioactive macromolecules, such as Tocopherol, Trigonelline, Nicotinic acid and D-chiro-inositol, found in pumpkin seeds, possess hypoglycemic properties and could assist in maintaining glycemic control $(27,28)$.

Because of their high $\beta$-sitosterol content, pumpkin seeds $(C$. pepo) are further used to treat benign prostatic hyperplasia (29) and overactive bladder (30), especially in German speaking countries where pumpkin seed is officially, since a few decades, in the German Pharmacopeia (Granu Fink ${ }^{\circledR}$ ) (31).

Finally, because of the high tryptophan content, pumpkin seeds might ease depression, anxiety, nervous irritability and insomnia $(6,32,33)$. Furthermore, they have shown to improve the iron status (34) and have blood-coagulatory effects $(6,35)$. Their multiflorane-type triterpenes have melanogenesis inhibitory activity and thus may be potential skin whitening agents (36). Pumpkin seed oil has shown to be effective for the treatment of hair growth in male patients with mild to moderate androgenetic alopecia (37). Table I summarizes the medicinal and pharmacological effects of Cucurbita sp. seeds.

\section{Allergenicity}

Allergy to pumpkin is considered a very rare disorder and so far only a few isolated case reports have been published. All parts of the fruit can be responsible for allergic symptoms.

\section{Cucurbita sp. peel}

Cucurbita sp. peel can cause allergic contact dermatitis $(38,39)$ after peeling and cutting-up uncooked Cucurbita species. (C. maxima varieties and butternut squash, respectively). Arochena et al. report a case of contact urticaria and angioedema of the face after handling onion and zucchini (C. pepo) with no symptoms after ingestion of cooked zucchini, for which an IgE-based mechanism was demonstrated (40). By analogy to the major allergen of melon peel (Cucumis melo), LTP could be one possible allergen for contact allergy to pumpkin (41).

\section{Curcurbita sp. pulp}

In 2000, Figuendo et al. publish the first case of immediate-type systemic reaction associating pharyngeal and generalized itching, angioedema of the face and mild dyspnoea after ingestion of pumpkin pulp (C. pepo) in a 28-year-old woman, with cross reactivity to cucumber, zucchini, muskmelon and watermelon, supported by positive prick-to-prick tests and positive challenge tests (42). In the same year, Reindl et al. report four cases of food allergy to raw and cooked zucchini (C. pepo), ranging from oral allergy syndrome to grade two anaphylaxis with digestive symp- 
Table I - Important bioactive compounds from pumpkin seeds and their biological activities.

\begin{tabular}{|c|c|c|}
\hline Specialty & Substance & Indications \\
\hline \multirow[t]{2}{*}{ Infectiology } & $\begin{array}{l}\text { moschin, MAP 2, MAP 4, MAP11, MAP28, } \\
\text { peptide (MW: } 8 \mathrm{kDa} \text { ), albumin } 2 S\end{array}$ & $\begin{array}{l}\text { bacterial and fungal infections of the skin, urinary tract } \\
\text { and intestine }\end{array}$ \\
\hline & cucurbitin, berberine, palmatine & intestinal helminthic infections \\
\hline Rheumatology & anti-inflammatory compounds & inflammatory diseases, arthritis \\
\hline \multirow[t]{2}{*}{ Gastroenterology } & hydroxyl pentacyclic triterpene acids & biliary vesicle problems \\
\hline & fiber & constipation \\
\hline \multirow[t]{3}{*}{ Dermatology } & linoleic acid, tocopherols, & wound healing \\
\hline & phytosterols & alopecia \\
\hline & multiflorane-type triterpene esters & hyperpigmentation disorders (melanogenesis inhibition) \\
\hline Ophthalmology & carotenoids & cataract \\
\hline Psychology & tryptophan & depression, anxiety, nervous irritability, insomnia \\
\hline Neurology & carotenoids, tocopherols & mental and physical ageing \\
\hline Gynecology & phytosterols & lactation, postpartum edema \\
\hline $\begin{array}{l}\text { Nephrology, Urology, } \\
\text { Andrology }\end{array}$ & $\begin{array}{l}\text { phytosterols ( } \beta \text {-sitosterol, delta-7-sterols), } \\
\text { lignans, carotenoids, tocopherols, omega } 3 \\
\text { and } 6 \text { fatty acids }\end{array}$ & $\begin{array}{l}\text { benign prostatic hyperplasia, bladder and kidney } \\
\text { stones, irritable bladder, enuresis nocturna, impotence }\end{array}$ \\
\hline Hematology & coumaric acid & blood coagulation \\
\hline $\begin{array}{l}\text { Cardiovascular } \\
\text { Disease, Metabolic } \\
\text { Syndrome }\end{array}$ & $\begin{array}{l}\text { polyphenols, lignans, phytosterols, omega- } 3 \\
\text { and omega- } 6 \text { fatty acids }\end{array}$ & $\begin{array}{l}\text { hypertension, hypercholesterolemia, dyslipidemia, } \\
\text { atherosclerosis, non-alcoholic fatty liver disease }\end{array}$ \\
\hline Diabetology & $\begin{array}{l}\text { trigonelline, nicotinic acid, D-chiro-inositol, } \\
\text { tocopherol, lignans }\end{array}$ & diabetes, hyperglycemia \\
\hline \multirow[t]{4}{*}{ Oncology } & $\begin{array}{l}\text { carotenoids, polyphenols, squalene, phytos- } \\
\text { terols, lignans }\end{array}$ & $\begin{array}{l}\text { gastric, breast, lung, prostate and } \\
\text { colorectal cancers }\end{array}$ \\
\hline & pumpkin $2 S$ albumin & $\begin{array}{l}\text { breast adenocarcinoma (MCF-7), ovarian } \\
\text { teratocarcinoma (PA-1), prostate cancer (PC-3 and } \\
\text { DU-145) and hepatocellular carcinoma (HepG2) cells }\end{array}$ \\
\hline & moschatin & melanoma \\
\hline & cucurmosin, MAP2, MAP4 & $\begin{array}{l}\text { melanoma, leukemia, lung adenocarcinoma } \\
\text { and pancreas cancer }\end{array}$ \\
\hline
\end{tabular}

toms or stridor (43). The first case of pediatric food anaphylaxis to pumpkin pulp (C. maxima) was published by Hagendorens in 2009 (44). Pumpkin can also be responsible for food-dependent exercise-induced anaphylaxis (45) or food protein-induced enterocolitis syndrome $(46,47)$.

Cucurbita sp. allergy can be isolated (43[three of the four cases]-46,48,49), but in some cases is correlated with clinical cross-allergenicity to other fruits of the cucurbitaceous family (cucumber, melon, and/or watermelon) $(42,43,50)$. Pumpkin pulp allergy can be part of the latex-fruit syndrome (51). Finally, it may be associated with sensitization to peach $(50,52)$.

For Cucurbita sp. pulp allergy, possible allergens could be profilin ( $15 \mathrm{kDa}$ protein, Cuc p 2, Cuc ma 2), LTP (8.9 kDa protein), cross-reacting carbohydrate determinants and zucchini-specific proteins of molecular weight of $16-17 \mathrm{kDa}$ and of $41.5 \mathrm{kDa}$ $(42,43,48,49)$. González De Olano et al. identify an $18 \mathrm{kDa}$ protein, corresponding to cyclophilin (Cuc ma CyP) as a relevant allergen for oral allergy syndrome to pumpkin (50). 


\section{Cucurbita sp. seed}

Only seven cases of food allergy after ingestion of pumpkin seeds have so far been reported, with one of them also presenting occupational contact urticaria to pumpkin seeds. All six subjects tolerated pumpkin pulp and other fruits of the cucurbitaceous family (cucumber, melon and/or watermelon) (1,12,53-55).

Fritsch et al. describe three cases of adult fishermen who experienced allergic symptoms immediately after ingestion of food containing pumpkin seed. The clinical symptoms ranged from oropharyngeal itching and swelling to bronchial asthma. The patients had previously been sensitized by inhalation of a pumpkinseed flour mixture in its powdered form during preparation of baits to lure fish (the baits were made of a mixture of corn bran, wheat bran, pumpkinseed flour and water and then molded into balls) (12).

Baur et al. report the particular case of an 18-year-old man with anaphylaxis associating pharyngeal swelling and dysphagia after eating rolls with pumpkin seed who three years later, when working as a baker, developed occupational contact urticaria to pumpkin seed (53).

Rodríguez-Jiménez record anaphylaxis with edema and erythema accompanied by a sensation of dyspnoea after ingestion of toasted pumpkin seeds (C. maxima species) in a 33-year-old pollen-allergic man who reported also facial edema and erythema after eating peach, apple, unpeeled pear, and orange (54).

Caubert et al. publish the first pediatric case of an 11-year-old boy with history of fish allergy and atopic dermatitis, who presented anaphylaxis with urticaria, angioedema and asthma after eating pumpkin seeds (1).

In a very recent report, Doll et al. describe a case of anaphylaxis in a 70-year-old woman with history of angioedema to shellfish. Almost immediately after ingestion of pumpkin seeds included in a trail mix, symptoms initiated with nausea and sense of impending doom and were followed by several syncopal episodes despite administration of an expired Epipen ${ }^{\circledR}$ (55). In accordance with Prieto-Gracia et al. (56) who describe two cases of food anaphylaxis with underlying mast cell disorder, the severity of the reaction (several syncopal episodes), the absence of cutaneous symptoms, especially hives, and a REMA score of $\geq 2$ might be suggestive of an underlying clonal mast cell order in Doll and al.'s patient, despite a normal baseline serum tryptase (55).

Set apart from these cases of food allergy to Cucurbita sp. seed, but worth including in our review, is a report of food allergy to egusi-itoo seeds (seeds of African pumpkin Cucumeropsis mannii), a species of another Cucurbitaceae genus, Cucumeropsis. An 8 -year-old Togolese girl presented an angioedema of the face after ingestion of egusi-itoo seeds, with no cross-allergy to pumpkin seeds of the Cucurbita species. A $60 \mathrm{kDa}$ protein, specific to African pumpkin seed, was identified (57).

Pumpkin seed sensitivity may be associated with allergy to other seeds as reported by Lavine et al. in a 3-year-old boy allergic to sunflower and poppy seeds (58).
The allergens of pumpkin seed have not been well characterized. Immunoblot studies on the sera of the three patients described by Fritsch et al. revealed a $14 \mathrm{kDa}$ protein which is probably a homologue of profilin, as it was completely inhibited by recombinant birch profilin. Besides the $14 \mathrm{kDa}$ protein, proteins of molecular weight of $13,36,48,69,77$, and $87 \mathrm{kDA}$ were detected (12). Rodríguez-Jiménez identified a $12 \mathrm{kDa}$ protein which however was not homologous to the lipid transfer protein of peach (pru p3), although the patient's clinical symptoms (concomitant allergy to peach, apple, unpeeled pear, and orange) suggested involvement of an LTP (54).

Potential allergens of edible seeds may correspond to storage proteins which are found in the seeds of a wide range of monoand di-cotyledonous plants. Their hydrolysis provides necessary amino acids during germination and to the growing plant. The storage proteins most abundantly found in seeds are cupins or salino-soluble globulins, to which belong $7 \mathrm{~S}$ globulins or vicilins and $11 \mathrm{~S}$ globulins or legumins. Other storage proteins are $2 S$ albumins. Their compact structure, their important size and abundance in the seeds, as well as their resistance to heat denaturation and to hydrolysis by digestive proteases are thought to be responsible for their important allergenic properties $(58,59)$. Cupins (7S vicilins and $11 \mathrm{~S}$ legumins) have been identified in sesame seed, and $2 \mathrm{~S}$ albumin storage proteins in both sesame and sunflower seed (60). The important sequential and structural homology of storage proteins of different origins may be responsible for cross-reactivity between different edible seeds, peanuts and tree nuts (58-60).

In our case, no clinical cross-allergenicity has been demonstrated. However, slightly positive $\mathrm{IgE}$ to hazelnut $11 \mathrm{~S}$ globulin (cor a 9) might be suggestive of biological cross-reactivity and implication of pumpkin specific $11 \mathrm{~S}$ globulin in the boy's anaphylactic reaction.

\section{Conclusions}

Because of their potential therapeutic effects in the prevention of cardiovascular disease, cancer and aging process, seeds like pumpkin seeds are increasingly included in many foods, in alternative or natural medicines and in cosmetics. Pumpkin seed food allergy may therefore be expected to augment in the future. It should be assessed by carefully taking the patient's medical history and by including common edible seeds in food allergy testing panels (e.g. sesame, sunflower, pumpkin, flax and poppy seed).

\section{References}

1. Caubet JC, Hofer MF, Eigenmann PA, Wassenberg J. Snack seeds allergy in children. Allergy 2010; 65(1):136-7.

2. Schaefer H, Renner SS. Phylogenetic Relationships in the Order Cucurbitales and a New Classification of the Gourd Family $(\mathrm{Cu}-$ curbitaceae). Taxon 2011; 60(1):122-38. 
3. Kumar SR. Cucurbits: History, Nomenclature, Taxonomy, and Reproductive Growth. in Handbook of Cucurbits: Growth, Cultural Practices, and Physiology. Mohammad Pessarakli CRC Press. 2016:3-21

4. https://hort.purdue.edu/newcrop/1492/cucurbits.html

5. http://academics.hamilton.edu/foodforthought/our_research_ files/cucurbitaceae.pdf

6. Yadav M, Jain S, Tomar R, Prasad GB, Yadav H. Medicinal and biological potential of pumpkin: an updated review. Nutr Res Rev 2010; 23(2):184-90.

7. Bisognin DA. Origin and Evolution of cultivated Cucurbits. Ciência Rural 2002; 32(5):715-23.

8. Smith BD. The initial domestication of C. pepo in the Anerucas 10,000 years ago. Science 1997; 276(5314):932-4.

9. Janick J, Paris HS, Parrish DC. The cucurbits of Mediterranean antiquity: identification of taxa from ancient images and descriptions. Ann Bot 2007; 100(7):1441-57.

10. Caili F, Huan S, Quanhong L. A review on pharmacological activities and utilization technologies of pumpkin. Plant Foods Hum Nutr 2006; 61(2):73-80.

11. Nawirska-Olszańska A, Kita A, Biesiada A, Sokół-Łętowska A, Kucharska AZ. Characteristics of antioxidant activity and composition of pumpkin seed oils in 12 cultivars. Food Chem 2013; 139(1-4):155-61.

12. Fritsch R, Ebner H, Kraft D, Ebner C. Food allergy to pumpkinseed-characterization of allergens. Allergy 1997; 52(3):335-7.

13. Kalogeropoulos N, Chiou A, Ioannou MS, Karathanos VT. Nutritional evaluation and health promoting activities of nuts and seeds cultivated in Greece. Int J Food Sci Nutr 2013; 64(6):757-67.

14. Kim MY, Kim EJ, Kim YN, Choi C, Lee BH. Comparison of the chemical compositions and nutritive values of various pumpkin (Cucurbitaceae) species and parts. Nutr Res Pract 2012; 6(1):21-7.

15. Veronezi CM, Jorge N. Bioactive compounds in lipid fractions of pumpkin (Cucurbita sp) seeds for use in food. J Food Sci 2012; 77(6):C653-7.

16. Bardaa S, Ben Halima N, Aloui F, Ben Mansour R, Jabeur H, Bouaziz M, Sahnoun Z. Oil from pumpkin (Cucurbita pepo L.) seeds: evaluation of its functional properties on wound healing in rats. Lipids Health Dis 2016; 15:73.

17. Tomar PP, Nikhil K, Singh A, Selvakumar P, Roy P, Sharma AK. Characterization of anticancer, DNase and antifungal activity of pumpkin 2S albumin. Biochem Biophys Res Commun 2014; 448(4):349-54.

18. Grzybek M, Kukula-Koch W, Strachecka A, Jaworska A, Phiri AM, Paleolog J, Tomczuk K. Evaluation of anthelmintic activity and composition of pumpkin (Cucurbita pepo L.) seed extracts-in vitro and in vivo studies. Int J Mol Sci 2016; 17(9) pii: E1456.

19. Medjakovic S, Hobiger S, Ardjomand-Woelkart K, Bucar F, Jungbauer A. Pumpkin seed extract: cell growth inhibition of hyperplastic and cancer cells, independent of steroid hormone receptors. Fitoterapia 2016; 110:150-6.

20. Richter D, Abarzua S, Chrobak M, Vrekoussis T, Weissenbacher T, Kuhn C, Schulze S, Kupka MS, Friese K, Briese V, Piechulla B, Makrigiannakis A, Jeschke U, Dian D. Effects of phytoestrogen extracts isolated from pumpkin seeds on estradiol production and ER/PR expression in breast cancer and trophoblast tumor cells. Nutr Cancer 2013; 65(5):739-45.

21. Xia HC, Li F, Li Z. Purification and characterization of moschatin, a novel type I ribosome-inactivating protein from the mature seeds of pumpkin (Cucurbita moschata), and preparation of its immunotoxin against human melanoma cells. Cell Res 2003; 13(5):369-374.

22. Hou X, Meehan EJ, Xie J, Huang M, Chen M, Chen L. Atomic resolution structure of cucurmosin, a novel type 1 ribosome-inactivating protein from the sarcocarp of Cucurbita moschata. J Struct Biol 2008; 164(1):81-7.

23. Zhang B, Huang H, Xie J, Xu C, Chen M, Wang C, Yang A, Yin $\mathrm{Q}$. Cucurmosin induces apoptosis of BxPC-3 human pancreatic cancer cells via inactivation of the EGFR signaling pathway. Oncol Rep 2012; 27(3):891-7.

24. Morrison MC, Mulder P, Stavro PM, Suárez M, Arola-Arnal A, van Duyvenvoorde W, Kooistra T, Wielinga PY, Kleemann R. Replacement of dietary saturated fat by PUFA-Rich pumpkin seed oil attenuates non-alcoholic fatty liver disease and atherosclerosis development, with additional health effects of virgin over refined oil. PLoS One 2015; 10(9):e0139196.

25. Gossell-Williams M, Lyttle K, Clarke T, Gardner M, Simon O. Supplementation with pumpkin seed oil improves plasma lipid profile and cardiovascular outcomes of female non-ovariectomized and ovariectomized Sprague-Dawley rats. Phytother Res 2008; 22(7):873-7.

26. El-Mosallamy AE, Sleem AA, Abdel-Salam OM, Shaffie N, Kenawy SA. Antihypertensive and cardioprotective effects of pumpkin seed oil. J Med Food 2012; 15(2):180-9.

27. Adams GG, Imran S, Wang S, Mohammad A, Kok MS, Gray DA, Channell GA, Harding SE. The hypoglycemic effect of pumpkin seeds, Trigonelline (TRG), Nicotinic acid (NA), and D-Chiro-inositol (DCI) in controlling glycemic levels in diabetes mellitus. Crit Rev Food Sci Nutr 2014; 54(10):1322-9.

28. Bharti SK, Kumar A, Sharma NK, Prakash O, Jaiswal SK, Krishnan S, Gupta AK, Kumar A. Tocopherol from seeds of Cucurbita pepo against diabetes: validation by in vivo experiments supported by computational docking. J Formos Med Assoc 2013; 112(11):676-90.

29. Damiano R, Cai T, Fornara P, Franzese CA, Leonardi R, Mirone V. The role of Cucurbita pepo in the management of patients affected by lower urinary tract symptoms due to benign prostatic hyperplasia: a narrative review. Arch Ital Urol Androl 2016; 88(2):136-43.

30. Nishimura M, Ohkawara T, Sato H, Takeda H, Nishihira J. Pumpkin seed oil extracted from Cucurbita maxima improves urinary disorder in human overactive bladder. J Tradit Complement Med 2014; 4(1):72-4.

31. https://online.rote-liste.de/suche/Granu\%20fink

32. Hudson C, Hudson S, MacKenzie J. Protein-source tryptophan as an efficacious treatment for social anxiety disorder: a pilot study. Can J Physiol Pharmacol 2007; 85(9):928-32.

33. Hudson C, Hudson SP, Hecht T, MacKenzie J. Protein source tryptophan versus pharmaceutical grade tryptophan as an efficacious treatment for chronic insomnia. Nutr Neurosci 2005; 8(2):121-7.

34. Naghii MR, Mofid M. Impact of daily consumption of iron fortified ready-to-eat cereal and pumpkin seed kernels (Cucurbita pepo) on serum iron in adult women. Biofactors 2007; 30(1):19-26.

35. Krishnamoorthi R, Gong YX, Richardson M. A new protein inhibitor of trypsin and activated Hageman factor from pumpkin (Cucurbita maxima) seeds. FEBS Lett 1990; 273(1-2):163-7.

36. Kikuchi T, Ueda S, Kanazawa J, Naoe H, Yamada T, Tanaka R. Three new triterpene esters from pumpkin (Cucurbita maxima) seeds. Molecules 2014; 19(4):4802-13.

37. Cho YH, Lee SY, Jeong DW, Choi EJ, Kim YJ, Lee JG, Yi YH, Cha HS. Effect of pumpkin seed oil on hair growth in men 
with androgenetic alopecia: a randomized, double-blind, placebo-controlled trial. Evid Based Complement Alternat Med 2014; 2014:549721.

38. Sinha S, Pasricha J, Sharma R, Kandhari K. Vegetables responsible for contact dermatitis of the hands. Arch Dermatol 1977; 113(6):776-9.

39. Potter TS, Hashimoto K. Butternut squash (Cucurbita moschata) dermatitis. Contact Dermatitis 1994; 30(2):123.

40. Arochena L, Gámez C, del Pozo V, Fernández-Nieto M. Cutaneous allergy at the supermarket. J Investig Allergol Clin Immunol 2012; 22(6):441-2.

41. Gandolfo-Cano M, Bartra J, González-Mancebo E, Feo-Brito F, Gómez E, Bartolomé B, Muñoz-García E, Sanz Maroto A, Vivanco F, Cuesta-Herranz J, Pastor-Vargas C. Molecular characterization of contact urticaria in patients with melon allergy. $\mathrm{Br} \mathrm{J}$ Dermatol 2014; 170(3):651-6.

42. Figueredo E, Cuesta-Herranz J, Minguez A, Vidarte L, Pastor C, De Las Heras M, Vivanco F, Lahoz C. Allergy to pumpkin and crossreactivity to other Cucurbitaceae fruits. J Allergy Clin Immunol 2000; 106(2):402-3.

43. Reindl J, Anliker MD, Karamloo F, Vieths S, Wüthrich B. Allergy caused by ingestion of zucchini (Cucurbita pepo): characterization of allergens and cross-reactivity to pollen and other foods. J Allergy Clin Immunol 2000; 106(2):379-85.

44. Hagendorens MM, Carrette M, Bridts CH, Stevens WJ, Ebo DG. Allergy from giant pumpkin (Cucurbita maxima) is not a fairy tale. Allergy 2009; 64(11):1694-6.

45. Kim SM, Yoo SH, Kim MK. A Case of Squash-dependent Exercise-induced Anaphylaxis. Korean J Asthma Allergy Clin Immunol 2011; 31(2):140-3.

46. Nowak-Wegrzyn A, Sampson HA, Wood RA, Sicherer SH. Food protein-induced enterocolitis syndrome caused by solid food proteins. Pediatrics 2003; 111(4 Pt 1):829-35.

47. Ruffner MA, Finegold DN, MacGinnitie AJ. Infant with unusual food reactions. Acta Paediatr 2011; 100(10):1289,1394-5.

48. Damiani E, Aloia AM, Priore MG, Nardulli S, Macchia L, Ferrannini A. Zucchini allergy: a case report. Rev Fr Allergol 2011; 51(5):515-6
49. Asero R, Mistrello G, Amato S. A case of allergy to zucchini. Eur Ann Allergy Clin Immunol 2012; 44(5):205-6.

50. González De Olano D, González-Mancebo E, Macadán SS, Cano MG, Pérez-Gordo M, Ortega BC, Vivanco F, Vargas CP. Allergy to pumpkin with cyclophilin as the relevant allergen. Ann Allergy Asthma Immunol 2010; 104(1):98-9.

51. Pereira C, Tavares B, Loureiro G, Lundberg M, Chieira C. Turnip and zucchini: new foods in the latex-fruit syndrome. Allergy 2007; 62(4):452-3.

52. La Shell MS, Otto HF, Whisman BA, Waibel KH, White AA, Calabria CW. Allergy to pumpkin and crossreactivity to pollens and other foods. Ann Allergy Asthma Immunol 2010; 104(2):178-80.

53. Baur X, Gahnz G. Allergy to pumpkin seed in the form of intolerance and Occupational contact urticaria: a case report. Dermatologie in Beruf und Umwelt 2002; 50(5):178-9.

54. Rodríguez-Jiménez B, Domínguez-Ortega J, Ledesma A, GonzálezGarcía JM, Kindelan-Recarte C. Food allergy to pumpkin seed. Allergol Immunopathol (Madr) 2010; 38(1):50-1.

55. Doll R, Johnson J, Peppers BP, Tcheurekdjian H, Hostoffer R. IgE-mediated anaphylactic shock caused by pumpkin seed in an adult. Ann Allergy Asthma Immunol 2017; pii: S10811206(16)31394-1.

56. Prieto-García A, Álvarez-Perea A, Matito A, Sánchez-Muñoz L, Morgado JM, Escribano L, Álvarez-Twose I. Systemic mastocytosis presenting as IgE-mediated food-induced anaphylaxis: a report of two cases. J Allergy Clin Immunol Pract 2015; 3(3):456-8.

57. Zana H, Moneret Vautrin DA, Guérin L, Kanny G, Leduc V. Allergie alimentaire isolée aux graines de courge africaine. Rev Fr Allergol 2005; 45(3):275.

58. Lavine E, Ben-Shoshan M. Allergy to sunflower seed and sunflower butter as proposed vehicle for sensitization. Allergy Asthma Clin Immunol 2015; 11(1):1-3.

59. Rougé P, Brunet E, Borges JP, Jauneau A, Saggio B, Bourrier T, Rancé F, Didier A, Barre A. Proteins with cupin motif as major seed allergens. Rev Fr Allergol 2011; 51(1):36-40.

60. Patel A, Bahna SL. Hypersensitivities to sesame and other common edible seeds. Allergy 2016; 71(10):1405-13. 